\title{
Increasing Teachers' Self-efficacy through Regular Teaching and Learning Supervision
}

\author{
Hareesol Khun-Inkeeree ${ }^{1, *}$, Mohd-Hibatul-Hakimie Mahmood ${ }^{2}$, Siti-Saadiah Haji-Mohd-Noor ${ }^{2}$, \\ Muhammad Dzahir Kasa ${ }^{2}$, Mohd Faiz Mohd Yaakob², M. S Omar-Fauzee', \\ Fatimah Noor Rashidah Mohd Sofian ${ }^{3}$ \\ ${ }^{1}$ School of Languages and General Education, Walailak University, Thailand \\ ${ }^{2}$ School of Education and Modern Languages, Universiti Utara Malaysia, Malaysia \\ ${ }^{3}$ Kulliyyah of Economics and Management Sciences, International Islamic University, Malaysia
}

Received March 31, 2020; Revised May 12, 2020; Accepted May 27, 2020

Copyright $(02020$ by authors, all rights reserved. Authors agree that this article remains permanently open access under the terms of the Creative Commons Attribution License 4.0 International License

\begin{abstract}
Circular Letter No 3/1987 issued by the Ministry of Education of Malaysia makes it clear that the supervision of teaching and learning in the classroom is the responsibility of the principal or headmaster to fulfill his role as supervisor. However, school administrators are still not emphasizing this dimension of teaching and teaching supervision, as a result, there may be shortcomings in the pedagogical skills and the quality of the teaching material of teachers. Recognizing the importance of supervisory processes to enhance teacher professionalism, this study was conducted to examine the relationship between teaching and learning supervision skills and teacher self-efficacy, as well as to examine the influence of teaching and learning supervision dimensions on teaching effectiveness. This study was conducted among 211 teachers who participated in the teaching and learning supervision process in 13 primary schools selected by the Jeli District Education Office, Kelantan. The questionnaire was used to collect data and information. Correlation analysis showed that there was a significant relationship between supervisory skills and teacher self-efficacy $(\mathrm{r}=0.44, \mathrm{p}=0.00)$, while regression analysis to examine the influence of teaching and learning supervision showed that the technical dimension was moderate $(\mathrm{r}=0.43, \mathrm{r} 2=0.185$, $\mathrm{p}<0.05)$ and the knowledge dimension was also moderate $(\mathrm{r}=0.45, \mathrm{r} 2=0.200, \mathrm{p}<0.05)$. This finding clearly shows that the quality of teaching and learning supervision will contribute to increased self-efficacy of teachers. The study also shows that the dimension of knowledge skills has the greatest impact on teacher self-efficiency. In summary, the quality of supervision of teaching and learning should not be neglected, as the findings of the study clearly show that these variables are related to teacher self-efficacy, which cannot be denied as a catalyst for the performance of a
\end{abstract}

school.

Keywords Teaching and Learning Supervision Skill, Teacher Self-efficacy, Supervisor, Teacher, Primary School

\section{Introduction}

Education contributes significantly to a country's economic and social capital production. It promotes imagination and stimulates innovation; it provides young people with the skills they need to succeed in the competitive labor market; and it is a key driver of economic development. And, because the Government has adopted steps to position Malaysia firmly on the road to development in the framework of the New Economic Model, the Economic Transformation Plan and the Policy Transformation Plan (GTP), the education system will continue to progress together. This will keep Malaysia on track in an increasingly competitive global economy. In 2013, the Ministry of Education launched the Malaysian Education Development Plan 2013-2025 (MEDP), overall through this plan, in particular efforts to generate high quality human capital to ensure that the education system is guided through the efforts, commitments and dedication of teachers, principals, officials and support staff to fulfill the aspirations of making Malaysia a high-income developed nation in the future. It is in line with the goal of producing excellent human capital which will be a key asset to drive the country towards achieving a high level of advanced and high income nation [1].

In line with the above suggestions, a study by [2] also 
found that teachers' leadership model of teaching also contributed to teacher teaching competencies and effectiveness. The findings of [4] show that leadership is an influential process, working together as a team and setting goals together. Therefore, the role of school administrators in particular as teaching and learning supervisors is essential to ensure that the process meets the goals and achieves the desired impact while holistically improving the effectiveness of teachers and, as a result, will benefit students' learning in the classroom and school as a whole. [5] define supervision as an organized function that is closely linked to teacher development, improved teaching performance and improved student learning quality. This finding is further supplemented by a study by [6] that emphasizes that supervisory effectiveness is a result of the quality of supervision that encompasses knowledge, interpersonal and technical skills. The quality of teaching and learning will be enhanced if all three factors are successfully applied. Aspects of knowledge include school direction, androgynous educational methods, teacher development and other alternative supervisory practices that can be explored and improved upon while interpersonal skills need to be mastered by supervisors to establish symbiotic relationship orientation and encourage change. In addition, supervisors also need to master technical skills to carry out planning, assessment, observation and assessment of teaching improvement. Overall, the three competencies (i.e., knowledge, interpersonal, and technical skills) are complementary and interrelated. As a result of effective supervision, professional culture and positive interactions can also be strengthened in the school environment through principals and principals' relationships with teachers, teacher-teacher relationships and teacher-student relationships. Supervision will also build a more positive and effective teacher attitude in their day-to-day tasks. In other words, supervisors, principals or headmasters should help to enhance the self-efficacy and professionalism of teachers by equipping themselves with adequate supervision knowledge [9]. Similar guidance was also shown by [7] who stated that lack of knowledge, interpersonal and technical skills related to the supervision process led to incompleteness and lack of effectiveness.

\section{Research Problems}

Today's educational world faces a challenging future, with a constant demand for concrete, systematic and holistic approaches and to address it, the quality of teaching and learning of teachers is one of the key focus in ensuring world-class student inclusion for competition in a globalized world. In this regard, the Malaysian Education Development Plan (MEDP) 2013-2025 has integrated the Malaysian Education Quality Standards (MEQS) which is one of the teaching and learning dimensions Education,
[10]. However, the lack of skills and competencies among principals, headmasters and supervisors who have been appointed has led to some negative impacts on them and supervised teachers. Further to emphasize this, the study by [11] stated that knowledge aspects, interpersonal skills and technical skills within supervisors need to be enhanced in order to help the Ministry of Education Malaysia develop effective schools. Supervisors' weaknesses in the aspects of supervision should be studied and given more focus. This is because, as Malaysia is moving towards the goal of high-income developed countries, the development of talented individuals should begin with quality teaching and learning in the classroom. In line with the findings of [12], we find that the formation of capable individuals begins with effective teaching and learning in the classroom, resulting from the impact of supervision. However, it is hampered by the low level of teacher effectiveness as a result of poor supervision and learning processes and will affect student achievement in schools such as studies by [13], [14].

To address this problem, teachers should be guided by a correct, fair, transparent and systematic procedure or system which can be used as an indicator for improving the progress and quality of targeted education. Accordingly, a study by [13] showed that the high level of effectiveness during the teaching and learning process in the classroom was closely related to student achievement and achievement in school. Moreover, a study by [7] also found that no special training was disclosed to supervisors regarding the implementation of supervision processes aimed at facilitating teacher teaching process. If supervision and guidance practices improve, teachers will feel that they are being supported and will improve their teaching quality. In addition, [15] also argue that supervisors need to be able to evaluate the effectiveness of the teaching and learning process and thus provide advice, guidance and encouragement for teachers.

Furthermore, [6] through their study found that instructional supervision during the teaching and learning process has assisted teachers formally in improving teaching and learning in the classroom. However, the lack of trust, competence, skills and supervisory skills among principals has caused some concern among teachers. Sometimes, supervisory responsibilities are delegated to subordinates who are unfamiliar with supervision and, in turn, impede teachers' confidence in their supervisors. This issue was supported by [16] through their study which stated that teacher supervision work is sometimes carried out by senior assistants, senior teachers and school committee leaders because principals need to attend meetings everywhere. In addition, another issue raised was the issue of supervisor professionalism. A study by [17] found that principals and responsible people sometimes do not take supervision seriously, but some of the teachers have never been supervised during their tenure. This study will indirectly identify issues and problems faced by 
principals and teachers in the process of supervising the teaching and learning of primary school teachers in Jeli district, Kelantan. A study by [18] shows that some teachers consider their professionalism to be questioned in the event of supervision. This scenario is due to the fact that they have mastered and equipped themselves with skills and courses of professionalism that do not require them to be supervised. Likewise, [19] in his study found that the supervisory process of teaching also found that there were also elements of persecution, inconsistency, confusion and bias because supervisors were not supervised, not serious and supervisors were ignored by supervised teachers. Earlier studies by [20] found that teachers felt that supervisory-focused supervision was a threat to them. On the other hand, the findings of [21] also found that not all teachers are able to identify their own teaching needs and are unable to accept the advice or support of others due to personal and professional differences. This is due to the lack of confidence in their supervisors in the supervision process in the classroom. Issues of bullying, the lack of professionalism, and poor interpersonal skills of principals or assistance principals need to be addressed through more systematic research to help address long-standing problems for teachers in schools [11].

In addition, principals and headmasters are required to carry out the teaching and learning supervision process in the classroom in accordance with [8] systematically complies with the principles and procedures for implementing the supervision as outlined. However, this aspect of the implementation of teaching and learning supervision is generally not emphasized by school administrators and as a result, it may lead to weaknesses in the interpersonal skills [22], pedagogical competencies and effectiveness of teaching content in teachers [10]. On this basis, this analysis must be carried out and the results will help to formulate a clearer and more concrete path for the education and teaching supervision process. A more detailed and systematic monitoring study by the headmasters should therefore be carried out with a view to assess their competence, in particular at the rural area school in Jeli, Kelantan.

\section{Hypothesis of the study}

In this study, five null hypotheses have been formulated as follows:

H01: There is no significant relationship between school teaching and learning supervision and self-efficacy of rural school teachers in Jeli district, Kelantan.

H02: There is no significant relationship between supervision knowledge and self-efficacy of rural zone school teachers in the Jeli district of Kelantan.

H03:There is no significant relationship between interpersonal skills in supervision and self-efficacy of rural zone primary school teachers in the Jeli district of Kelantan.

$\mathrm{H} 04$ :There is no significant relationship between technical skills in supervision and self-efficacy of teachers in a rural zone primary school district in Jeli district, Kelantan.

H05: The dimensions of teaching and learning supervision skills do not significantly influence teacher self-efficacy levels in rural zone primary school district of Jeli, Kelantan.

\section{Materials and Methods}

\subsection{Sampling}

Based on the sampling form [23], this study was conducted on 205 respondents consisting of teachers from 13 primary schools in a rural zone in Jeli district, Kelantan. All primary schools in the Jeli district are placed in two zones under the jurisdiction of the Jeli District Education Office. The urban zone has two primary schools while the rural zone has 13 primary schools. According to the Jeli District Education Office's ICT Unit, there are 217 male teachers and 325 female teachers in primary schools comprising various backgrounds and educational levels. For rural areas in particular, there are 183 male teachers and 254 female teachers. Referring to the [23] sampling formula, a total of 246 sets of questionnaires including $20 \%$ oversampling were distributed to the respondents through selected school principals and gave their consent to assist in the above study. Generally, teachers involved as respondents have been directly involved in the supervision process of teaching and learning in the classroom. To avoid bias, school administrators acting as supervisors were excluded from answering this survey.

\subsection{Instrument of Study}

The research questionnaire is divided into 3 main sections. Part A is used to obtain teachers' personal information containing four question items namely gender, age, teaching experience and academic approval. Parts B, $\mathrm{C}$ and $\mathrm{D}$ cover the knowledge, interpersonal and technical skills contained in the school management supervision skills, which are independent variables consisting of 24 question items. Effective strategies of instructional strategies, levels of classroom management effectiveness and levels of student engagement are respectively E, F and $\mathrm{G}$, related to teacher self-efficacy. This teacher-level questionnaire was administered using the Ohio State Teacher Efficacy Scale (OSTES), which consisted of 24 question items and was a dependent variable.

Parts B, C and D of this questionnaire are related to supervisory skills by school management. [6] through Development Supervision Model-Development 
Supervision on development supervision models has identified elements of knowledge, interpersonal skills and technical skills elements as essential elements for each supervisor to enable them to be effective supervisors.

Knowledge elements are represented by Section B, elements of interpersonal skills are represented by section $\mathrm{C}$ while technical skills are represented by section D. All items contained in these three sections of the questionnaire were modified from [29] questionnaire. Part B of this survey has eight questions adapted from the Confidence in the Principal Supervisor dimension to look at teachers 'perceptions of supervisors' beliefs, supervisor leadership aspects, communication between supervisors and teachers and improve the quality of teaching they receive after the supervision process implemented in the school.

To review elements of supervisor interpersonal skills, Part C consisted of eight questions developed based on the Principal Support Supervision of Teaching dimension in [29] questionnaire, which assesses the aspects of supervisor support provided for teachers based on positive and harmonious relationships between supervisors and teachers supervised: Supervisory attitude that is supportive, helps to improve continuously, is caring, open-minded, trustworthy and always focuses on teacher supervision needs.

Part D is the final part of the school management supervision skills aimed at assessing the technical skills of a supervisor. There were eight questions adapted from [29] questionnaire, which is from the Active Supervision Supervision section.

Part E consisted of eight questions representing the effective elements of the instructional strategies Efficacy for instructional strategies used in the teaching and learning process in the classroom. It will evaluate teachers in their ability to diversify assessment strategies, the ability to provide alternative explanations, the ability to formulate good questions, the ability to implement alternative strategies, to provide feedback, to challenge students more prominently and to tailor pedagogy to student achievement.

Furthermore, Section F also has eight questions related to teachers' ability to manage students in the classroom, Efficacy for classroom management. The questions raised are about how teachers can do something to help students create a positive and conducive learning climate with approaches to controlling behavior disruption; ensuring rules are followed, calming student harassment, establishing a classroom management system, responding to students who resist., building a clear expectation of student behavior and building a routine for controlling classroom activities.

Part G, Efficacy for student engagement, also features eight teachers 'questions in convincing students to do their best, helping students to value learning, motivating students who are less motivated to work, helping students' families encourage them excel, improve student understanding, encourage critical thinking skills, encourage creativity, address problematic learners and encourage student learning in the classroom.

\subsection{Questionnaire Translation}

This questionnaire was developed in western countries and in order to address cross-cultural problems and misunderstandings, it has to be translated using back to back translation method to ensure its reliability and validity. As such it involves a questionnaire translation process as suggested by [30]. And in meeting the needs of this study, it was translated from English to Malay. Two English teachers with a Bachelor's Degree in Teaching English as a Second Language Teaching English for Second Language (TESL) have assisted in the process of translating the instrument to be used. A teacher translated the questionnaire from English to Malay, while a teacher again translated it back into English. After the translation process is complete, the instrument will be re-compared to ensure the accuracy of the translation. Subsequently, ready-to-translate instruments will be referred to the supervisor for accuracy and final validation purposes.

\subsection{Pilot Study}

According to [31], the pilot study was an experimental study to verify the level of reliability, consistency and validity of the items contained in the questionnaire to be completed by the actual study sample but it was only conducted on the same group of respondents. Similarly, the findings of [42] found that the pilot study was conducted to determine the validity and reliability of the instrument developed. This finding is further reinforced by further findings by [32] who detailed four advantages of pilot studies, which enable researchers to test their hypotheses, add new ideas that were not considered necessary before pilot studies, conduct detailed research in statistical procedures and data analysis and allow the researcher to consider whether the study is feasible or not. Later, this finding was further added to the statement of [33] that stated that although the questionnaire was developed and tested with a pilot study and back-to-back translation process, a pilot study still needs to be conducted in order for the questionnaire distribution process to receive positive response from the respondents. In the scope of this study, a total of 30 sets of pilot studies were distributed at a rural school in the district of Kota Bharu and in line with the findings of [34], the sample for pilot studies was at least 10 percent of the total sample size of study.

\subsection{Instrument Reliability}

[35] based on the results of his study stated that a variable is considered to be reliable when the instrument is consistent. Earlier studies by [36] defined consistency as the value of the tested item giving the same or almost 
identical value to the original instrument used. The instrument reliability test was conducted using the 64-bit version of the Statistical Package for the Social Sciences (SPSS) and had a cronbach's alpha value as follows. Tables 1 and 2 show the Cronbach's alpha values for this research questionnaire for teaching and learning supervision skills dimensions and teacher self-efficacy.

Table 1. Reliability Analysis of Teaching and Learning Supervision Skills

\begin{tabular}{|c|c|c|}
\hline Dimensions & Item Numbers & Alpha Value $(\boldsymbol{\alpha})$ \\
\hline Knowledge & 8 & 0.89 \\
\hline Interpersonal Skills & 8 & 0.92 \\
\hline Technical Skills & 8 & 0.91 \\
\hline
\end{tabular}

Table 2. Reliability Analysis of Teacher Self-Efficacy

\begin{tabular}{|c|c|c|}
\hline Dimensions & Item Numbers & Alpha Value $(\boldsymbol{\alpha})$ \\
\hline Instructional Strategy & 8 & 0.84 \\
\hline Classroom Management & 8 & 0.86 \\
\hline Students Engagement & 8 & 0.86 \\
\hline
\end{tabular}

\subsection{Study Procedures}

Before data are collected and the results of the study are reported, the researcher must first obtain permission from Awang Had Saleh Salleh Graduate School (AHSGS), University of North Malaysia. Following approval, the researcher will need to obtain further approval from the Education and Research Planning Division (EPRD) of the Ministry of Education of Malaysia to submit further applications to the Kelantan State Education Department for the purpose of obtaining approval for the distribution of questionnaires in selected schools.

Next, the researcher will contact the school principal as head of the department and inform the scope of the study to be carried out. Researchers have sought the help of senior assistants or school administrators to help distribute the questionnaire to the respondent teacher in order to make the process smoother and easier. In the briefing session on the administration of the questionnaire, the respondents were informed that they were given a week to complete and return the questionnaire. Researchers need to give written instructions to the respondents to inform them of the time allocated to complete the questionnaire. Respondents were also assured that their feedback would be confidential and would not adversely affect the respondents.

\section{Results}

After field studies, all data collected were analyzed using IBM Statistical Package for The Science Social version 24.0 64-bit software (IBM SPSS 24.0) and operated on a Microsoft Windows 8.1 64-bit platform.
The reports provided relate to the respondents 'demographics, descriptive statistical analysis of frequency, percentage, mean and standard deviation to describe the respondents' profile and answer the research questions. Inference statistics, Pearson Correlation and Stepwise Regression were also used to test differences and relationships between variables and the hypotheses of the study.

\section{5. .1Respondent's Profile}

The respondents in this study were 211 teachers consisting of 13 teachers in 13 rural zone primary schools in Jeli district, Kelantan. A total of 246 sets of questionnaires were distributed and 211 sets of questionnaires were collected by the researchers for analysis. The number of respondents involved was determined through the [23] formula and the respondents would provide information on the respondents' gender, age of the respondent, teaching experience of the respondent and academic approval of the respondents.

\section{5. .2Respondents Gender}

Table 3. Respondents Gender Distribution

\begin{tabular}{|c|c|c|}
\hline Gender & Numbers & Percent (\%) \\
\hline Male & 59 & 28.0 \\
\hline Female & 152 & 72.0 \\
\hline Total & 211 & 100.0 \\
\hline
\end{tabular}

\subsection{Respondents Age}

Table 4. Respondents Age Distribution

\begin{tabular}{|c|c|c|}
\hline Teacher's Age Range & Numbers & Percent (\%) \\
\hline 25-29 Years & 5 & 2.4 \\
\hline 30-34 Years & 11 & 5.2 \\
\hline 35-39 Years & 58 & 27.5 \\
\hline 40-44 Years & 83 & 39.3 \\
\hline 45-49 Years & 31 & 14.7 \\
\hline 50-55 Years & 20 & 9.5 \\
\hline 56-60 Years & 3 & 1.4 \\
\hline Total & 211 & 100.0 \\
\hline
\end{tabular}

\section{5. .4Teaching Experience}

Table 5. Teaching Experience Distribution

\begin{tabular}{|c|c|c|}
\hline Teaching Experience & Numbers & Percent (\%) \\
\hline $1-5$ Years & 54 & 25.6 \\
\hline $6-10$ Years & 114 & 54.0 \\
\hline $11-15$ Years & 40 & 19.0 \\
\hline $16-20$ Years & 3 & 1.4 \\
\hline
\end{tabular}




\section{5..5 Academic Qualification}

Table 6. The Academic Qualification of Respondents

\begin{tabular}{|c|c|c|}
\hline Academic Qualification & Numbers & Percent (\%) \\
\hline Diploma & 21 & 10.0 \\
\hline Bachelor Degree & 168 & 79.6 \\
\hline Master Degree & 22 & 10.4 \\
\hline Total & 211 & 100.0 \\
\hline
\end{tabular}

\section{5..6 Supervisory Skills Level}

Table 7. Supervisory Skills Analysis of Supervisors at primary schools district of Jeli district, Kelantan

\begin{tabular}{|c|c|c|c|}
\hline Skills & N & Mean & SD \\
\hline Supervisory Skills & 211 & 4.13 & 0.38 \\
\hline Knowledge & 211 & 4.15 & 0.38 \\
\hline Interpersonal Skills & 211 & 4.22 & 0.45 \\
\hline Technical Skills & 211 & 4.03 & 0.43 \\
\hline
\end{tabular}

The data analysis of supervisory skills level in the primary schools of the Jeli district rural area is shown in Table 7. The results showed that supervision skills by supervisors at Jeli district rural schools were high $(\mathrm{M}=$ $4.13, \mathrm{SD}=0.38)$ with the highest interpersonal skills level $(\mathrm{M}=4.22, \mathrm{SD}=0.45)$ followed by the dimensions knowledge $(\mathrm{M}=4.15, \mathrm{SD}=0.38)$ and technical skill dimensions $(\mathrm{M}=4.03, \mathrm{SD}=0.43)$. The findings show that teaching and learning supervisors have high supervisory skills and are translated through the three dimensions provided.

\section{5..7 Teacher Self Efficacy Level}

Table 8. The Self Efficacy Level among Teachers

\begin{tabular}{|c|c|c|c|}
\hline Dimensions & N & Mean & SD \\
\hline Teacher Self Efficacy & 211 & 3.91 & 0.33 \\
\hline $\begin{array}{c}\text { Instructional Strategy } \\
\text { Efficacy }\end{array}$ & 211 & 3.87 & 0.38 \\
\hline $\begin{array}{c}\text { Classroom Management } \\
\text { Efficacy }\end{array}$ & 211 & 3.98 & 0.38 \\
\hline $\begin{array}{c}\text { Students Engagement } \\
\text { Efficacy }\end{array}$ & 211 & 3.90 & 0.36 \\
\hline
\end{tabular}

The data analysis of the self-efficacy levels of teachers in the primary schools of the Jeli district rural area is shown in Table 8. The results showed that the level of teacher self-efficacy in the Jeli district rural school was moderate $(\mathrm{M}=3.91, \mathrm{SD}=0.33)$ with the highest classroom management effectiveness dimension $(\mathrm{M}=3.98, \mathrm{SD}=0.38)$ followed by the dimension student engagement effectiveness $(\mathrm{M}=3.90, \mathrm{SD}=0.36)$ and instructional strategy effectiveness $(\mathrm{M}=3.87, \mathrm{SD}=0.38)$. The findings of this study show that the self-efficacy level of rural primary school teachers in the Jeli district is high.

\subsection{Statistical Analysis of Inference}

There are five hypotheses in this study and researchers will use Pearson and Stepwise Regression correlation statistics to state the strength of the relationship between the two variables, namely teaching and learning supervision levels and teacher self-efficacy.

\subsection{Test the Hypothesis}

Ho1: There is no significant relationship between school teaching and learning supervision and self-efficacy of rural school teachers in Jeli district, Kelantan.

Table 9. The relationship between school teaching and learning supervision and self-efficacy

\begin{tabular}{|c|c|}
\hline Test & Teacher Self Efficacy \\
\hline Correlation & $.44^{* *}$ \\
\hline Sig.(two tailed) & .000 \\
\hline $\mathrm{N}$ & 211 \\
\hline
\end{tabular}

** Correlation is sig.at a level of confidence of 0.01 (two tailed).

To answer this hypothesis, the Pearson Correlation test was used and is shown in Table 9. This study aimed to identify the relationship between teaching and learning supervision skills and teacher self-efficacy in 13 rural zone primary schools in the Jeli district. Findings show that teaching and learning supervision skills on teacher self-efficacy have a positive and significant positive relationship with correlation coefficients $(\mathrm{r}=0.44, \mathrm{p}=$ 0.00 ). Thus, the null hypothesis that there was no significant relationship between school management supervision skills and self-efficacy of rural school teachers in the Jeli district was rejected.

Ho2: There is no significant relationship between supervision knowledge and self-efficacy of rural zone school teachers in the Jeli district of Kelantan.

Table 10. The relationship between supervision knowledge and self-efficacy

\begin{tabular}{|c|c|}
\hline Test & Teacher \\
\hline Correlation & $.39 * *$ \\
\hline Sig.(two tailed) & .000 \\
\hline $\mathrm{N}$ & 211 \\
\hline
\end{tabular}

** Correlation is sig. at a level of confidence of 0.01 (two tailed).

To answer this hypothesis, the Pearson Correlation test was used and is shown in Table 10. This study aimed to identify the relationship between knowledge of supervision and teacher self-efficacy in 13 rural zone primary schools in the Jeli district. Findings indicated that knowledge relations in supervision and teacher self-efficacy had a weak and a significant positive correlation with correlation coefficients $(r=0.39, p=0.00)$. Therefore, the null hypothesis that there was no significant relationship between supervisory knowledge and self-efficacy of rural 
zone primary school teachers in the Jeli district was rejected.

Ho3: There was no significant relationship between interpersonal skills in supervision and self-efficacy of rural zone primary school teachers in the Jeli district of Kelantan.

Table 11. The relationship between interpersonal skills in supervision and self-efficacy

\begin{tabular}{|c|c|}
\hline Test & Teacher Self Efficacy \\
\hline Correlation & $.39^{* *}$ \\
\hline Sig.(two tailed) & .000 \\
\hline $\mathrm{N}$ & 211 \\
\hline
\end{tabular}

** Correlation is sig. at a level of confidence of 0.01 (two tailed).

To answer this hypothesis, the Pearson Correlation test was used and is shown in Table 11. This study aimed to identify the relationship between interpersonal skills in supervision and teacher self-efficacy in 13 rural zone primary schools in the Jeli district. Findings showed that the relationship of interpersonal skills in supervision with teacher self-efficacy had a weak and significant positive correlation with correlation coefficients $(r=0.39, p=0.00)$. Therefore, the null hypothesis that there was no significant relationship between interpersonal skills in supervision and self-efficacy of rural zone primary school teachers in the Jeli district was rejected.

Ho4: There was no significant relationship between technical skills in supervision and self-efficacy of teachers in a rural zone primary school district in Jeli district, Kelantan.

Table 12. The relationship between technical skills in supervision and self-efficacy of teachers

\begin{tabular}{|c|c|}
\hline Test & Teacher \\
\hline Correlation & $.43^{* *}$ \\
\hline Sig.(two tailed) & .000 \\
\hline N & 211 \\
\hline
\end{tabular}

** Correlation is sig. at a level of confidence of 0.01 (two tailed).

To answer this hypothesis, the Pearson Correlation test was used and is shown in Table 12. This study aimed to identify the relationship between technical skills in supervision and teacher self-efficacy in 13 rural zone primary schools in the Jeli district. Findings showed that the relationship of interpersonal skills in supervision with teacher self-efficacy had a positive and significant positive relationship with correlation coefficient $(\mathrm{r}=0.43, \mathrm{p}=0.00)$. Thus, the null hypothesis that there was no significant relationship between technical skills in supervision and self-efficacy of rural zone primary school teachers in the Jeli district was rejected.

Ho5: The dimensions of teaching and learning supervision skills do not significantly influence teacher self-efficacy levels in rural zone primary school district of
Jeli, Kelantan.

Table 13. Fifth Null Hypothesis

ANOVA Results in Multiple Regression

\begin{tabular}{|c|c|c|c|c|c|c|}
\hline \multicolumn{2}{|c|}{ Model } & $\begin{array}{c}\text { Sum of } \\
\text { Squares }\end{array}$ & df & $\begin{array}{c}\text { Mean } \\
\text { Squares }\end{array}$ & F & Sig. \\
\hline \multirow{3}{*}{1} & Regression & 4.195 & 1 & 4.195 & 47.493 & $.000^{\mathrm{b}}$ \\
\cline { 2 - 7 } & Residual & 18.461 & 209 & .088 & & \\
\cline { 2 - 7 } & Total & 22.656 & 210 & & & \\
\hline \multirow{2}{*}{2} & Regression & 4.542 & 2 & 2.271 & 26.076 & $.000^{\mathrm{b}}$ \\
\cline { 2 - 7 } & Residual & 18.114 & 208 & .087 & & \\
\cline { 2 - 7 } & Total & 22.656 & 210 & & & \\
\hline
\end{tabular}

a. Rational Variables: Mean Self-Efficacy of Teachers

b. Predictors: (Constants), Mean Technical Skills

c. Predictors: (Constants), Technical Skills, Knowledge

\section{Meanings}

Table 13 shows that regression models for predicting teacher self-efficacy by two types of models predicting technical skills $(\mathrm{F}=47.50, \mathrm{p}>.05)$ against teacher self-efficacy and two models predicting knowledge $(\mathrm{F}=$ $26.08, p>.05)$ on teacher self-efficacy. One possible conclusion is that the technical skills dimension has the highest predictability and importance for teacher self-efficacy. The dimensions of interpersonal skills are not included in the table above as these dimensions are not direct predictors of teacher self-efficacy.

Table 14. Results of Multiple Regression Analysis Using Stepwise Methods on the Teacher Self-Efficacy Level

Model Summary ${ }^{\mathrm{c}}$

\begin{tabular}{|c|c|c|c|c|c|}
\hline Model & $\mathbf{R}$ & $\begin{array}{c}\mathbf{R} \\
\text { Square }\end{array}$ & $\begin{array}{c}\text { Adjusted } \\
\text { R Square }\end{array}$ & $\begin{array}{c}\text { Std. } \\
\text { Error of } \\
\text { the } \\
\text { Estimate }\end{array}$ & $\begin{array}{c}\text { Dubin- } \\
\text { Watson }\end{array}$ \\
\hline 1 & $.430^{\mathrm{a}}$ & .185 & .181 & .29720 & \\
\hline 2 & $.448^{\mathrm{b}}$ & .200 & .193 & .29510 & 1.871 \\
\hline
\end{tabular}

a. Predictors: (Constant), Mean Technical Skills

b. Predictors: (Constant), Mean Technical Skills, Mean Knowledge

\section{c. Dependent Variables: Mean Self-Efficacy of Teachers}

Based on Table 14 above, the predictor of the technical skills dimension was moderate to teacher self-efficacy ( $\mathrm{r}$ $=.43, \mathrm{r} 2=.185, \mathrm{p}<0.05)$. For teachers of technical skills and knowledge of teacher self-efficacy $(r=.45, r 2=.200, p$ $<0.05$ ), the difference between model one and model two was only $1.8 \%$.

\section{Discussion}

Based on the findings of this study, it is found that the level of teaching and learning supervision skills of all head 
teachers and senior assistants in rural primary schools in the district of Jeli is high and has been shown to be of high mean score $(\mathrm{M}=4.13, \mathrm{SD}=0.38)$, as a result of the data analysis process of the 211 respondents involved. The findings of this study are consistent with the study by [14] with 16 primary schools in the central Melaka district of Malacca, which found that the effectiveness and professionalism of teachers increased as a result of professionalism between supervisors and teachers $(\mathrm{M}=$ 3.97), experience and knowledge $(\mathrm{M}=3.97)$, and supervisors who assist teachers in the teaching process (M $=4.04$ ). A total of 88.9 percent of respondents felt that the classroom supervision process helped to improve the quality of teaching and learning as perceived weaknesses would be identified and would work to overcome them and make continuous improvement in the future. The study also found that 80.0 percent of teachers felt that the supervision process allowed them to establish a harmonious and positive relationship between the supervisor and the teacher. It is an important step in fostering a sense of achievement and self-esteem in a supervised teacher.

Further, studies by [7] involving 210 teachers in seven missionary schools in Penang found that the teaching and learning supervision skills dimension is high $(\mathrm{M}=3.81, \mathrm{SD}$ $=0.63$ ), which is lower than the self-efficiency level of primary rural teachers in the Jeli district. The findings of the study have shown that the quality of supervision carried out by the supervisors is capable of building positive elements within the teacher, such as being able to leverage and develop existing potentials, enhancing leadership values, being able to communicate more effectively, improving aspects of curriculum development and maximizing potential resources, and is consistent with the [24], [25] studies. This study as a whole concludes that effective supervision of teaching and learning will have a positive impact on improving the efficiency and overall professionalism of teachers. The findings of this study also indicate that the level of self-efficacy of teachers in Jeli district rural primary schools is high $(\mathrm{M}=3.9, \mathrm{SD}=0.39)$ and it is interpreted that teachers are very concerned about student engagement during the teaching and learning process, teachers able to manage the teaching and learning climate in the classroom, teachers able to diversify instruction. In addition, a study by [7] in Penang involving 210 teachers in seven missionary schools found that their overall level of self-efficacy was high $(\mathrm{M}=4.14, \mathrm{SD}=0.39)$ and that their level of self-efficacy was higher than the overall level of self-efficacy of rural school teachers in Jeli. The findings of the teacher self-efficacy study were conducted in three dimensions, namely learning strategies, classroom management and student involvement in the classroom. A study by [26] on 97 (Quranic Teaching JQAF) trainee teachers at the Teacher Teaching Campus in Ilmu Khas Kuala Lumpur also showed that they were at a high level $(\mathrm{M}=4.15, \mathrm{SD}=0.38)$ and this finding further proves that the quality of the teaching and learning supervision process by the teacher supervisor as the classroom supervisor also contrles. Highly qualified teachers will seek the causes of student weaknesses, plan, set goals, identify strategies, strive for goals, always have fun with assignments, and have the confidence to constantly transform their students from failure to improvement. From a deeper perspective, teachers in the Jeli district's rural area of primary school district have a high level of self-efficacy for teachers in all dimensions. The highest dimension was classroom management efficiency $(\mathrm{M}=3.98, \mathrm{SD}=0.38)$, the second highest was student engagement effectiveness $(\mathrm{M}=3.9, \mathrm{SD}=0.36)$ and the third highest was educational strategy effectiveness $(\mathrm{M}=3.86$, $\mathrm{SD}$ 0.38). These indicators show that these three dimensions are consistently practiced by teachers as they carry out the teaching and learning process and manage students in the classroom. This high practice of self-efficacy indicates that teachers have sufficient self-preparation prior to the teaching and learning process and thus attract students and that the content delivery process will be of the same quality as the findings of the [13] studies.

The results of the Pearson correlation analysis showed that there was a simple and significant positive correlation with the coefficient of correlation $(r=0.44, p=0.001)$ between school supervision skills and teacher efficiency. This situation shows that school supervision skills have a positive and significant relationship with the level of self-efficiency of primary school teachers in rural areas of the Jeli district. Previous studies by [13] also showed that there was a moderate and significant positive correlation between the quality of school supervision and the level of effectiveness of teachers $(\mathrm{r}=0.41, \mathrm{p}<0.05)$. A further study by [27] of 291 respondents from 50 primary schools in the Papar district found that there was a significant relationship between the quality of teaching and teaching supervision and the level of effectiveness of teachers $(r=0.30, p<0.05)$. As such, this finding reinforces the findings of other previous studies that the quality of teaching and learning supervision will contribute to improving teacher self-efficiency and ultimately to catalyzing the excellence and performance of a school. However, a recent study by [7] found that there was a very low and significant positive relationship between teaching and learning supervision quality and teacher self-efficacy $(\mathrm{r}=0.19, \mathrm{p}<0.05)$. This study also shows that teachers have a high level of expectations for supervisors if the supervisor possesses and applies supervisory skills, such as supervisory knowledge, interpersonal skills and high technical skills. As a result, supervised teachers will be more confident and contribute to improving student achievement. Confidence of teachers in supervisors, support for supervisors and aspects of active supervision by principals, directors or senior assistants [9] are important factors determining the level of effectiveness of teachers.

The relationship between school supervision skills and teacher productivity rates exists since Jeli's rural district primary school headmaster and senior assistant both emphasize aspects of teaching and teaching supervision 
skills in the classroom. At the same time, teachers' self-efficacy relationships in a specific school are affected. Supervisors have been assisted in the implementation of teaching and learning supervision by using the Standard Instrument Form 4: Education and Learning issued by the Ministry of Immigration and Quality Assurance, Malaysia, which covers 12 key areas and should be used as scoreboard during teaching supervision sessions in the classroom. Scores 1 through 6 shall be given to the professional judgment of the supervisor on the basis of the score description guide for each of the 12 sections. The supervision implementation is further strengthened by the recommendation of the [28] that the Principals or Principals carry out the supervision and supervision of the school yearly program and comply with the mandatory responsibilities of Principals or assistant Principals in each school [8]. The Pearson correlation analysis showed a weak and significant positive correlation with the coefficient of correlation $(r=0.39, p=0.00)$ between supervisory knowledge and teacher self-efficacy. This finding shows that the knowledge contained in the teaching and learning supervisors has a weak and a significant positive relationship with the teacher self-efficiency level in the Jeli rural primary school district. Previous studies by [11] also found that a similar relationship was a weak and a significant positive relationship $(\mathrm{r}=.26, \mathrm{p}<0.01)$ between knowledge of supervision and competence and the elements found in teacher self-efficiency. The findings of this study conclude that a low level of supervisory knowledge among supervisors has led to a low level of teacher competence during the supervision of teaching and learning in the classroom.

This partnership exists because teachers are committed to and trust their teaching and learning supervisors. Teachers are also pleased with school leadership, as supervisors use a variety of communication strategies, have fair supervision decisions, have comprehensive knowledge of successful teaching techniques [43]. Their supervisors also have a background in supervisory techniques and supervisors are also able to improve the standard of teaching in the classroom and are in line with the elements described in [29] questionnaire. Pearson's correlation analysis of the dimensions of interpersonal supervision skills and teacher self-efficacy showed a weak and a significant positive relationship $(\mathrm{r}=0.39, \mathrm{p}=0.00)$, contrarily to a study by [13] which found that interpersonal supervisor skills had the strongest relationship $(\mathrm{r}=0.79, \mathrm{M}$ $=4.02, \mathrm{SD}=0.70)$. And the study also stated that supervisors should continue to support teachers to improve the teaching and learning process in the classroom. A study by [11] on the relationship of interpersonal skills to competence and the elements found in teacher self-efficacy found a weak and positive relationship $(\mathrm{r}=.26, \mathrm{p}<0.01)$. In other words, the low positive relationship and interpersonal skills of supervisors make a significant contribution to teaching skills during the teaching and learning supervision process in the classroom.
Previous studies by [45] have shown that high-quality interpersonal school leaders and working directly with teachers will indirectly help to improve school achievement, and this further reinforces the finding that the role of head teachers in particular plays a significant role in improving teacher self-efficiency. Studies by [37] also suggest that organizational culture is one of the determinants of employee self-efficacy and, in the context of this study, refers to the collaboration and harmonious relationship that exists between school supervisors and teachers. The findings of this study are further reinforced by the findings of [38], which suggest that teachers should be open to sharing their practices with those around them and achieve higher levels of maturity as they are one of the key aspects of the professional development of teachers. Studies by Thomas, [39], [44] have shown that mentoring practices are a form of support that teachers need to improve their professionalism and competence. It is also important for leaders to create and maintain a harmonious working environment so that communication and mutually supportive aspects consistently promote a more positive and effective aspect of communication [4].

In general, the high level of collegiality among school staff is a critical factor in the performance of a school. Collaborative and interpersonal interactions between teachers and colleagues should be encouraged to engage in academic, financial, emotional and professional practice. Discipline helps teachers and school administrators, as teaching and learning supervisors, to build organizational environments that provide comfort and flexibility while at the same time enhancing their performance and integrity in a harmonious and supportive setting, the results of Pearson's analysis of the relationship between technical supervision skills and teacher self-efficiency. This finding clearly shows that the technical skills of the teaching and learning supervisors of the Jeli district primary school in rural areas have a positive and significant positive relationship with the self-efficacy of teachers. The findings of this study are in contrast to a study conducted by [11] who found a weak and significant positive relationship $(r=0.26, p<0.01)$ between the technical skills of supervisors and the elements-elements in teacher self-efficacy. Poor positive relationships and poor technical skills have contributed to poor classroom teaching and learning.

The findings of this study are consistent with the study by [40] which found that the technical skills applied during clinical supervision had a positive impact on the quality of the teaching plan, the production of inductions, the teaching process, student questioning techniques, student engagement level, student activities, assignments and training, as well as their examination. The study found that $(\mathrm{M}=80.19, \mathrm{SD}=11.45)$ was obtained prior to the supervision process and increased following the supervision process $(\mathrm{M}=88.24, \mathrm{SD}=7.19)$. In other words, the mean after absorption is higher than the mean before absorption. The Stepwise regression analysis of the dimensions of teaching and learning supervision skills on 
the self-efficacy of Jeli district rural primary school teachers found that there were two significant influences, namely technical skills and knowledge dimensions. However, the dimensions of the interpersonal skills of supervisors in the teaching and learning supervision process did not have a significant impact on the self-efficacy of teachers. The technical skills dimension was $(\mathrm{r}=.43, \mathrm{r} 2=.185, \mathrm{p}<0.05)$ while the knowledge dimension was $(\mathrm{r}=.45, \mathrm{r} 2=.200, \mathrm{p}<0.05)$ indicating that there was a moderate effect on both dimensions.

\section{Future Recommendations of the Study}

The findings of this study will allow stakeholders such as the Ministry of Education of Malaysia, School Inspectors, State Education Department, District Education Office, Principals and Teachers to identify and take the best and most effective steps to improve teaching supervision and classroom learning skills among school administrators. The 1996 National Education Act made it clear that the objective of implementing supervision of teaching and learning in the classroom is to ensure that the quality of teaching and learning is effectively implemented and must be improved over time. In this regard, the responsibilities and trusts assumed by the school supervisor are crucial in ensuring that the school supervision process is carried out in accordance with the prescribed procedures and specifications. In addition, the effective supervision will directly increase the effectiveness of teachers [21]. However, this cannot be achieved without the presence of professional relationships, interpersonal skills and effective communication between supervisors and supervised teachers. Consequently, the results of this study found that aspects of training prior to supervision, positive and favorable management of the learning environment and systematic and planned supervision of teachers should be highlighted by those who can formulate more holistic and concrete policies and directions. Watkins, Callahan, and Visu (2019) [41] also suggested "a simple, straightforward way of thinking about supervision session flow - the Supervision Session Pyramid - as a teaching tool for use in supervisor education (pg. 1)". The flow process shifts from broad to narrow 1) Event / issue identification and clarification, 2) Exploration and collaboration, 3) Experimental and consolidation, and 4) Review and resolution.

Moreover, the findings of this study may provide some implications for managers and officials of the Malaysian Ministry of Education, the State Department of Education, and school teaching and learning supervisors to make consistent improvements over the long term. This study was conducted to identify the relationship between teacher supervision and teaching skills with teacher self-efficacy, and also to examine the impact of teaching supervision and learning dimensions on the self-efficacy of rural primary school teachers in the Jeli district. As a result, the level of supervisory skills can be assessed in more detail in relation to the level of self-efficacy of teachers. Three dimensions of supervisory skills, knowledge, interpersonal skills and technical skills of supervisors should be identified in more detail to enable researchers to see the strength of their relationship to self-efficiency in teaching. The findings of the study show that the three dimensions are high but have a moderate and weak relationship with the teacher's self-efficacy. Supervisors as managers of the organization need to pay attention to certain teachers who see teaching and learning supervision as a process that does not contribute to their professional development as teachers. Improving the professionalism and self-efficacy of teachers is inversely linked to student achievement levels and will contribute to overall organizational performance. The closest stakeholders and their responsibilities to primary schools in the rural district of Jeli, the Jeli District Education Office, were expected to focus more on two influences on the medium and low level of knowledge and technical skills of supervisors. [29] Supervision Theory through Principal Teaching Support needs to be given a more detailed focus on principals so that the teaching and learning supervision process is optimized for quality and success in order to achieve a learning environment for students. The goal of creating a high impact teaching and learning supervision process will not be achieved unless these skills are eliminated. It is hoped that the findings from this study will contribute to improving the overall quality of the nation's education and generating capital internationally respected, high-performing and highly-skilled people, in turn, responded to the call for Malaysia's National Transformation 2050 (TN50) and achieved the goal of making Malaysia a high-income developed nation.

\section{Limitation of the Study}

The study has its own limitations; (1) As school administrators may not prioritize the aspects of integrating teaching and teaching supervision, the purpose of teacher supervision can therefore be questioned. The limitation of this study only focuses on the supervision of teachers without evaluating who directed the supervision, the principal or other senior teachers. As a result, this study has not been able to compare the effectiveness of supervision between them. A further study is most likely to focus on this issue, 2). Inaddition, the level of trust and nervousness among teachers, in particular between the regular teaching classes and the supervised classes, should also be analyzed. Understanding the attitude of teachers towards these two different situations will help the State Education Department to develop proper supervision techniques, such as the "Supervision Session Pyramid" suggested by[41] should be tested in such a way that the nervousness factors of teachers observed during 
supervision can be reduced, 3) The study is also limited in the small number of participants. More teachers, including rural and urban school areas, should be included in future studies in order to provide a better picture of the current status of teacher supervision, and 4) Longitudinal studies and mixed methods (e.g. quantitative and qualitative study design) will definitely be undertaken in future in order to get a true image of teacher supervision's effectiveness.

\section{REFERENCES}

[1] "Muhyiddin...." (May 13, 2014). Muhyiddin: Govt on track to becoming high-income nation.The Star Newspaper. Retrieved from https://www.thestar.com.my/news/nation/2014/05/13/muhy iddin-govt-on-track-to-becoming-highincome-nation.

[2] I. Mohd Yusri., A. Aziz. Model Kepimpinan Pengajaran Pengetua dan Kompetensi Pengajaran Guru. Jurnal Kurikulum \& Pengajaran Asia Pasifik, vol 2, No.1, 11-25. 2014.

[3] A. E. Ngadiman, D. Ratmawati. Influence of transformational leadership and organization climate to the work satisfaction, organizational commitment and organizational citizenship behavior on the educational personnel of Sebelas Maret University, Surakarta. European Journal of Business and Management, vol. 5, No. 10, 97-114. 2013.

[4] M. Y. Mohd Faiz, H. Noor Hashimah, Y. Mat Rahimi, O.F. Mohd Sofian, A. A. Muhammad Noor, K-I. Hareesol, H. Akhmad, W. B. Khuan. Critical Success Factors of Sustainable Leadership: Evidence from High-achievement School. Universal Journal of Educational Research, Vol. 8, No. 5, 1665 - 1675. 2020. doi: 10.13189/ujer.2020.080502.

[5] J. Nolan, L. Hoover. Teacher supervision and evaluation: Theory into practice (3rd ed.). San Francisco: Wiley/Jossey-Bass. 2011.

[6] Glickman, C. D., Gordon, S. P., \& Ross-Gordon, J. V. Supervision and instructional leadership: A developmental approach (9th ed.). Boston: Pearson. 2014.

[7] J. Mardhiah, A. A. R. Rabiatul Hubungan kualiti enyeliaan pengajaran dengan efikasi kendiri guru. Jurnal Kepimpinan Pendidikan, Vol. 3, No. 3, 1-15. 2016.

[8] Ministry of Education. Surat pekeliling ikhtisas bil. 3/1987: Penyeliaan pengajaran pembelajaran di dalam kelas oleh Pengetua/Guru Besar Sekolah. Kuala Lumpur: Ministry of Education. 1987.

[9] M. Dimyati, Y. Supriyati, M. Akbar. Analysis of the effect of supervision, self- efficacy, and work commitments on teacher's professionality (Case study: Junior high school in East Jakarta-Indonesia). International Journal of Innovative Technology and Exploring Engineering, Vol. 8, No. 6, 99-103. 2019.

[10] Ministry of Education Pelan Pembangunan Pendidikan Malaysia 2013-2025: Pendidikan prasekolah hingga lepas menengah. Putrajaya, Malaysia: Ministry of Education. 2013.
[11] P. Darishah, Y. Daud, M. S. O. Fauzee. Teaching and learning supervision by school management, attitude of teachers and competency of teaching. International Journal of Development and Sustainability, Vol. 6, No.10, 1368-1381. 2017.

[12] C. Danielson, T. L. McGreal. Teacher Evaluation to Enhance Professional Practice. Princeton, NJ: Educational Testing Service. 2000.

[13] M. Y. Nurahimah, O. Rafisah. Hubungan kualiti penyeliaan pengajaran dan pembelajaran di bilik darjah dengan efikasi guru. Asia Pacific Journal of Educators and Education, Vol. 25, 53-71. 2010.

[14] S. Hamdan. A. R. Rahimah. Amalan penyeliaan pengajaran dan pembelajaran di sekolah-sekolah kebangsaan di daerah Melaka Tengah, Melaka. Fakulti Pendidikan, Universiti Teknologi Malaysia.Malaysia. 2011.

[15] A. J. E. James, R. Balasandran. Kepimpinan Instruksional: Satu Panduan Praktikal (Edisi Kedua). Kuala Lumpur: PTS Publications and Distributions. 2012.

[16] I. Sarimah, P. Chia, H. Rohana. Komponen penyeliaan pengajaran dan pembelajaran guru-guru teknikal di Malaysia. Paper presented at the Seminar Kebangsaan Majlis Dekan Pendidikan IPTA 2012, Johor Bahru, Malaysia. 2012.

[17] A. Z. Abdul Razak. Ciri Iklim Sekolah Berkesan: Implikasi Terhadap Motivasi Pembelajaran. Jurnal Pendidikan Islam, Vol. 31, 3-19. 2006

[18] S. Abdull Sukor. Hubungan motivasi, keupayaan mengajar dan komitmen kerja dengan prestasi kerja guru Bahasa Melayu sekolah menengah. Sintok: UUM Press. 2003.

[19] Mofareh, A. School-based instructional supervision in Saudi Arabian Public Secondary Schools (PhD dissertation). Department of Education, University of York. 2011.

[20] B. Malm. Towards a new professionalism: enhancing personal and professional development in teacher education. Journal of Education for Teaching, Vol. 35, 77-91. 2009.

[21] H. Khun-inkeeree. P. D. Dali. Y. Daud, M.S.B.O. Fauzee, R. Khalid. Effects of Teaching and Learning Supervision on Teachers Attitudes to Supervision at Secondary School in Kubang Pasu District, Kedah. International Journal of Instruction, Vol. 12, No. 1, 1335-1350. 2018.

[22] J. Knight. Unmistakable impact: A partnership approach fro dramatically improving instruction. Thousand Oaks, CA: Corwin. 2011.

[23] R. V. Krejcie. D. W. Morgan. Determining Sample Size for Research Activities. Educational and Psychological Measurement, Vol. 30, 607-610. 1970.

[24] J. T. Lovell, K. Wiles. Supervision for Better Schools (5th ed.). Upper Saddle River, N.J.: Merrill/Prentice Hall. 2004.

[25] P. F. Olivia, G. E. Pawlas. Supervision for today's schools. Hoboken, N.J.: Wiley Publishing Inc. 2004.

[26] A. Norlela, M. Mohd Munaim. Pengaruh kualiti penyeliaan pengajaran dan pembelajaran ke atas efikasi guru. Institut Pendidikan Guru Kampus Ilmu Khas, Kuala Lumpur. 2013.

[27] A. Dayang Mahani. Hubungan kualiti penyeliaan pengajaran dan pembelajaran dengan efikasi guru sekolah rendah. 
Masters thesis. Universiti Malaysia Sabah. 2013.

[28] Kementerian Pendidikan Malaysia. Sistem Pengurusan Sekolah Kualiti MS ISO 9001. Kuala Lumpur: Ministry of Education. 2008.

[29] H. Ebmeier. How supervision influences teacher efficacy and commitment: an investigation of a path model. Journal of Curriculum and Supervision, Vol. 18, No. 2, 110-141. 2003.

[30] R. W. Brislin, W. J. Lonner, R. M. Thorndike. Cross-Cultural Research Methods. New York: John Wiley \& Sons. 1973.

[31] K. Mohd Majid. Kaedah Penyelidikan Pendidikan. Kuala Lumpur: Dewan Bahasa dan Pustaka. 1994.

[32] H. Fauzi. A. Jamal, Z. N. Mohd Saifoul. Kaedah penyelidikan \& analisis data SPSS. Sintok: Universiti Utara Malaysia Press. 2014.

[33] A. Ahmad Kamal Ariffin, I. Rahman. A. Zuraidah. (2015). Factors affecting the teachers' motivation towards the implementation of teaching supervision in secondary schools. Journal of Advanced Review on Scientific Research, Vol. 12, No. 1, 1-10. 2015.

[34] Treece, E. W., \& Treece, J. W. (1982). Elements of research in nursing (3rd ed.). St. Louis, MO: Mosby

[35] Y. P. Chua. Kaedah dan statistik penyelidikan: kaedah penyelidikan. Kuala Lumpur: McGraw Hill. 2011.

[36] R.A. Howard. Uncertainty about Probability: A Decision Analysis Perspective. Risk Analysia: An International Journal, Vol. 8, No. 1, 91-98. 1988.

[37] Ngang. The effect of transformational leadership on school culture in male' primary schools Maldives. Procedia -Social and Behavioral Sciences, Vol. 30, No. 0, 2575-2580.
[38] K. Vangrieken, C. Meredith, E. Kyndt. Teacher communities as a context for professional development: A systematic review. Teaching and Teacher Education, Vol. 61, 47-59. 2017.

[39] E. E. Thomas, D. L. Bell, M. Spelman, J. Briody. The growth of instructional coaching partner conversations in a prek-3rd grade teacher professional development experience. Journal of Adult Education, Vol. 44, No. 2, 1-6. 2015.

[40] V. Arsaythamby, M. A. K. Mary. Kesan penyeliaan klinikal terhadap prestasi pengajaran guru sekolah menengah. Asia Pacific Journal of Educators and Education, Vol. 28, 81-102. 2013.

[41] C. E. Watkins, J. L. Callahan, L-I. Vîșcu. The common process of supervision process: The supervision session pyramid as a teaching tool in the beginning supervision seminar. Journal of Contemporary Psychotherapy, (no vol), (1-6). doi:10.1007/s10879-019-09436-5. 2019.

[42] Y. P. Chua. (2006). Kaedah penyelidikan: Buku 1. Kuala Lumpur: McGraw Hill. 2006

[43] Y. Daud, P. Darishah, M.S.O. Fauzee. Teaching and learning supervision, teachers' attitude towards classroom supervision and student participation. International Journal of Instructions, Vol. 11, No. 4, 513-526. 2018.

[44] E. Elsenberg. The Path to Progress: Instituting a culture of coaching this school year. Literacy Today, (July-August), 10-12. 2016.

[45] M.E. Barber. D. Meyerson. The gendering of school leadership: reconstructing the principalship. School leadership study: Developing successful principals. Paper prepared for the Annual Meeting of the American Educational Research Association, Stanford Educational Leadership Institute, Chicago, IL, April 9-13, 2007. 